\title{
Building Capacity for Quality Assurance in Global Higher Education
}

\author{
Robert E. Waller ${ }^{1}$, Pamela A. Lemoine ${ }^{2}$, Evan G. Mense ${ }^{3} \&$ Michael D. Richardson ${ }^{1}$ \\ ${ }^{1}$ Columbus State University, Columbus, Georgia, USA \\ ${ }^{2}$ Troy University, Troy, Alabama, USA \\ ${ }^{3}$ Southeastern Louisiana University, Hammond, Louisiana, USA \\ Correspondence: Michael D. Richardson, Columbus State University, Columbus, Georgia, USA.
}

Received: October 31, 2019

Accepted: January 30, 2020

Online Published: March 5, 2020

doi:10.20849/jed.v4i1.718

URL: https://doi.org/10.20849/jed.v4i1.718

\begin{abstract}
As a result of changing missions, quality assurance in global higher education has ascended to the top of the higher education policy agenda in many nations. In order to hold universities accountable despite limited governmental support, many nations have adopted performance-based university funding strategies. Increasingly citizens and bureaucrats in many countries are asking more frequently what tangible benefits the society is receiving for the revenues being spent on higher education. The marketing, selling and financing of higher education has had both positive and negative effects on the future of global higher education because stakeholders are increasingly asking whether students are learning and whether institutions are providing a quality of service that justifies their cost. How do global higher education institutions develop and initiate techniques and programs to promote quality assurance for teaching and learning? Globalization and accountability create an atmosphere in higher education where knowledge and information are more vastly prized and more highly globalized than are localized economic concerns. Can quality assurance provide the framework for the implementation and development quality higher education in a climate of change and ambiguity?
\end{abstract}

Keywords: quality assurance, accountability, productivity, competitive advantage, global higher education, capacity for change

\section{Introduction}

The road ahead for global higher education is filled with challenges, risks and uncertainties while simultaneously viewed increasingly as a major contributor to economic development (Moodie, 2016). Since the 1990s, global universities, in response to government pressure, have become more business-like and enterprising to take advantage of the 'opportunities' presented by the so-called global knowledge economy. This process of corporatization of higher education is tied to increasing enrollments and intensification of educational quality assurance of online learning (Thambusamy, Singh, \& Ramly, 2019).

Global higher education operates in a continually fluid and uncertain environment where government is ultimately responsible for the development of higher education in every country. The most obvious trends are those that support the hypothesis that the better the higher education system, the better the economy and the more productive the country (Marshall, 2018). Both the social and economic future of countries depends heavily on the educational attainment of their population and the quality of their higher education institutions (Balan, 2015).

One of the most impactful resources available to global higher education to increase its productivity is technology (Pucciarelli \& Kaplan, 2016. However, as information and communications technology continue to grow exponentially, faculty and administrators in higher education feel constant pressure to adopt and maintain up-to-date computer and network hardware and software while fighting a never-ending battle against technology obsolescence (Altbach \& Reisberg, 2018). With technology use becoming both a sociological phenomenon, a business application, and a method for teaching and learning, higher education institutions have struggled to keep up with the latest forms of technology (Lemoine, Jenkins, \& Richardson, 2017). Technology makes the business of higher education more complicated and competitive each day (Audretsch, Lehmann, \& Wright, 2014). 
In addition, perceptions of quality appear to be changing. The growing emphasis on outcomes and standards appears to herald the promise of more dramatic techniques for assessing and evaluating teaching within a global context (Lewis \& Lingard, 2015). Global higher education institutions are facing decreased funding during a time of scarce resources yet increased accountability for productivity in the development and articulation of knowledge (Wihlborg \& Robson, 2018). However, technology has disrupted the traditional, formal processes of higher education (Hogan, 2015) with the accompanying challenges of ensuring quality and accountability to the public sector that provides part of the funding, and to the students that are dependent on those educational models for their own socioeconomic security (Mense, Lemoine, Garretson, \& Richardson, 2018). With the challenges provided by a climate of change that appears to be accelerating, global higher education is negotiating a crossroads where the institution is subject to constant change (Lemoine \& Richardson, 2019).

\section{Accountability}

Accountability has been a concern for education for as long as higher education institutions have existed. In today's environment, globalization of the 21 st century fuels the current interest in accountability because the future of the world is tied inextricably to education and education appears to be functionally coupled with technology (Austin \& Jones, 2018). The long-range purpose of accountability is to enhance productivity. Accountability is necessary to measure quantitatively the investment of educational technology because education is about the utilization of and often consumption of human resources. In practical accountability measures, an output represents results (Beerkens, 2015).

Efficiency and effectiveness must go together in global higher education institutions. Educational organizations can temporarily survive without perfect efficiency; they usually die if they are ineffective. The mutual goals of increased efficiency and improved effectiveness are critical to accountability (Kallio, Kallio, \& Grossi, 2017). Efficiency typically implies a short-term response to accountability, while effectiveness specifies a long-term reaction. It is easier to rate how well a thing is done rather than measuring whether what is being done is right or not (Lodge, 2014).

Globally, higher educational institutions have been subjected to externally driven demands for accountability that have not proven to be effective. Irrespective of the ineffectiveness, numerous countries have advocated strong external accountability without understanding the low organizational capacity of the educational institutions to deliver critical productivity (Macdonald, 2014). The size of the accountability movement indicates that the survival of global higher education may very well hinge on the ability of the institutions to demonstrate productivity and accountability in a chaotic marketplace where even the indicators of productivity are undergoing change resulting in measures that have questionable reliability (Sabio \& Junio-Sabio, 2014).

\section{Productivity}

Reformers have advocated strong external productivity standards without understanding the low organizational capacity of global higher education institutions to deliver critical productivity (Caspersen, Frolich, \& Muller, 2017). Productivity is a measure of the efficiency and effectiveness of an organization in serving its customers that provides a basis for assessing how specified resources (inputs) are managed to produce acceptable outputs. In its most elementary expression, productivity is the relationship between input and output. In the case of global higher education, one important input is human capital, but always in terms of social imperatives of either the good of the individual to the group or the obverse. Productivity is expected to be higher in proportion to the intelligence, knowledge, ability and attitude with which that human capital is applied, i.e., performance (Davis, 2017).

In global higher education it should be noted that producing more by consuming more human capital does not result in higher productivity, but in higher labor costs. At the same time, productivity measures are subject to debate. For example, colleges and universities have long been expected to contribute to the knowledge base in many fields. As knowledge slowly accumulates, often in the form of conflicting research results or scholarly debates, a field will move forward in fits and starts and sudden shifts. The accumulation of knowledge is difficult for those leading institutions of higher education to evaluate in terms of efficiency or return-on-investment (Srivastava \& Suman, 2018). Often, the measurement is nothing more than a benchmark related to numbers of publications or presentations by department or faculty member. Similar measures such as number of credit hours tell only part of the story of productivity related to education as a commodity. Measurements related to the contribution of a university to the economy of a region, for example, is also difficult to quantify (Blanco-Ramirez \& Berger, 2014).

There is a push from globalization forces for organizational change in global higher education to increase the production of research and training in order to be accountable to governments. Consequently, there appears to be 
a shift towards the economic needs of society at the expense of learning. The information, knowledge and digital economies place greater prominence on productive and economic work meaning new methods of teaching and learning are necessary if global higher education is to survive and prosper (Carnoy, 2014).

\section{Quality Assurance}

Quality assurance gives a global educational institution the evidence it needs to make substantial changes to enhance productivity. The key concept is determining how to measure productivity in service organizations like universities and colleges (Biesta, 2017). Measurement standards for global higher education have been outlined by organizations and accrediting agencies, although not always consistently (Asif \& Searcy, 2014). Quality assurance, in response to calls for measurement in global higher education measures the capability and capacity of learning rather than the accumulation of a set of skills. As the world is changing global higher education is progressing toward a global platform of delivery and accommodation. As a result, higher education administrators now focus on quality assurance applications (Christensen, Gornitzka, \& Ramirez, 2019).

As the funding for educational programs becomes more stringent, the demand for quality assurance is more pressing (Chan, Richardson, \& Jording, 2001). When the public is urging global higher education institutions and programs to move toward quality assurance, it is essential that leaders assure their program quality.

\section{Assuring Quality in Global Higher Education}

The literature in building the capacity for quality assurance in higher education is rich. Measuring the amount of growth that each institution is expected to contribute to a knowledge base can prove to be difficult when knowledge slowly accumulates, research results conflict, and issues related to such knowledge are debated for years (West \& Thompson, 2015). Around the world global higher education leaders are forced to objectify, measure and quantify persons, programs and processes. The discrepancy of quantity over quality creates an unhealthy ethos in the global higher education institution that threatens to destroy the very programs that quality assurance is designed to measure (Tierney \& Almeida, 2017).

One model of quality assurance in global higher education includes the academic, student, and social evaluation components (Barton \& Ryan, 2014). Other criteria of quality education indicators include institutional mechanisms for course approval and monitoring, course design and delivery methods, staff qualifications and appointment procedures, student support services, assessment procedures and criteria, and course management. These indicators should be identified and developed as quality measuring criteria in alignment with the institution's mission and value system (Chen \& Mathies, 2016). Also emphasized in the assurance of program quality should indicate increased demands on the learners in terms of the acquisition of knowledge and skills, the capacity for conceptualization, and increasing autonomy in learning (Tam, 2014). In implementing a quality assurance program, concerns have been expressed about potential decreases in some institutions in enrollment and incompletion of the competency areas (Dunkerly \& Wonh, 2017). Another concern often expressed was that the cumbersome process of acquiring evidence of quality education could possibly overburden institutes of their core role of providing education (Moore \& Greenland, 2017). There are several strategic issues that could help shape the structure and function of the next generation of quality assurance to include the following:

- Goal compatibility: Ideally the goals of the higher education institution should be compatible with all stakeholders. (This will take work.)

- Meaningful procedures: Quality assurance measures must be meaningful and realistic and capable of gathering and measuring without bias.

- Professional foundation: Professionalism is needed by all those involved in the quality assurance process without preconceived notions brought to the activity (Lemoine, Hackett, \& Richardson, 2016).

\section{Conclusions}

(1) Assurance of program quality is an outcome of the educational accountability movement.

(2) The demand for quality programs is driving global higher education institutions to critically examine their program quality.

(3) Educational programs of all levels need to demonstrate their achievement to justify the educational investment.

(4) If 'quality' is the most desirable aspect of global higher education, then it should be the focal point of all policies related to education.

(5) The development of an implementation plan is recommended to assure program quality. 
(6) Program quality assurance processes need to be periodically reviewed and amended for practical implementation.

(7) Global higher education should focus on the quality of learning and their commitment to bring solutions to society.

(8) Global higher education must meet new standards of quality demanded by an increasingly technological, diverse, and knowledge-based society.

(9) The only sustainable competitive advantage is continuous innovation; in other words, the application of new knowledge.

(10) Quality assurance is essential for global higher education institutions.

\section{References}

Altbach, P. G., \& Reisberg, L. (2018). Global trends and future uncertainties. Change: The Magazine of Higher Learning, 50(3-4), 63-67. https://doi.org/10.1080/00091383.2018.1509601

Asif, M., \& Searcy, C. (2014). A composite index for measuring performance in higher education institutions. International Journal of Quality \& Reliability Management, 31(9), 983-1001. https://doi.org/10.1108/IJQRM-02-2013-0023

Audretsch, D. B., Lehmann, E. E., \& Wright, M. (2014). Technology transfer in a global economy. The Journal of Technology Transfer, 39(3), 301-312. https://doi.org/10.1007/s10961-012-9283-6

Austin, I., \& Jones, G. A. (2018). Emerging trends in higher education governance: Reflecting on performance, accountability and transparency. In E. Hazelkorn, H. Coates, \& A. C. McCormick (Eds.), Research handbook on quality, performance and accountability in higher education. Cheltenham, UK: Edward Elgar Publishing.

Balán, J. (2015). The crisis of the public mission in higher education. International Higher Education, (80), 4-5. https://doi.org/10.6017/ihe.2015.80.6130

Barton, G., \& Ryan, M. (2014). Multimodal approaches to reflective teaching and assessment in higher education. Higher Education Research \& Development, 33(3), 409-424. https://doi.org/10.1080/07294360.2013.841650

Beerkens, M. (2015). Quality assurance in the political context: In the midst of different expectations and conflicting goals. Quality in Higher Education, 21(3), 231-250. https://doi.org/10.1080/13538322.2015.1111004

Biesta, G. (2017). Education, measurement and the professions: Reclaiming a space for democratic professionality in education. Educational Philosophy and Theory, 49(4), 315-330. https://doi.org/10.1080/00131857.2015.1048665

Blanco-Ramírez, G., \& Berger, J. (2014). Rankings, accreditation, and the international quest for quality: Organizing an approach to value in higher education. Quality Assurance in Education, 22(1), 88-104. https://doi.org/10.1108/QAE-07-2013-0031

Carnoy, M. (2014). Globalization, educational change, and the national state. In N. P. Stromquist, \& K. Monkman (Eds.), Globalization and education. Integration and contestation across cultures (pp 21-38). Lanham, MD: Rowman \& Littlefield.

Caspersen, J., Frølich, N., \& Muller, J. (2017). Higher education learning outcomes-Ambiguity and change in higher education. European Journal of Education, 52(1), 8-19. https://doi.org/10.1111/ejed.12208

Chan, T. C., Richardson, M. D., \& Jording, C. (2001, October). Planning for educational accountability. Paper presented at the Annual Conference of the International Society for Educational Planning, Atlanta, Georgia.

Chen, P. D., \& Mathies, C. (2016). Assessment, evaluation, and research. New Directions for Higher Education, 2016(175), 85-92. https://doi.org/10.1002/he.20202

Christensen, T., Gornitzka, A., \& Ramirez, F. O. (2019). Reputation management, social embeddedness, and rationalization of universities. In T. Christensen, A. Gornitzka, \& F. O. Ramirez (Eds.), Universities as agencies (pp. 3-39). Cham, Switzerland: Palgrave Macmillan. https://doi.org/10.1007/978-3-319-92713-8_1

Davis, A. (2017). Managerialism and the risky business of quality assurance in universities. Quality Assurance in Education, 25(3), 317-328. https://doi.org/10.1108/QAE-06-2016-0027 
Dunkerly, D., \& Wonh, W. S. (2017). Global perspectives on quality in higher education. New York, NY: Routledge. https://doi.org/10.4324/9781315209890

Hogan, J. (2015). Reshaping the university: the rise of the regulated market in higher education. Perspectives: Policy and Practice in Higher Education, 19(1), 33-34. https://doi.org/10.1080/13603108.2014.963728

Kallio, K. M., Kallio, T. J., \& Grossi, G. (2017). Performance measurement in universities: Ambiguities in the use of quality versus quantity in performance indicators. Public Money \& Management, 37(4), 293-300. https://doi.org/10.1080/09540962.2017.1295735

Lemoine, P. A., \& Richardson, M. D. (2019). Creative disruption in higher education: Society, technology and globalization. In P. Peres, F. Moreira, \& A. Mesquita (Eds.), Educational and social dimensions of digital transformation in organizations (pp. 275-293). Hershey, PA: IGI. https://doi.org/10.4018/978-1-5225-6261-0.ch011

Lemoine, P. A., Hackett, P. T., \& Richardson, M. D. (2016). Higher education at a crossroads: Accountability, globalism and technology. In W. Nuninger, \& J.-M. Chatelet (Eds.), Handbook of research on quality assurance and value management in higher education (pp 27-57). Hershey, PA: IGI. https://doi.org/10.4018/978-1-5225-0024-7.ch002

Lemoine, P. A., Jenkins, W. M., \& Richardson, M. D. (2017). Global higher education: Development and implications. Journal of Education and Development, 1(1), 58-71. https://doi.org/10.20849/jed.v1i1.253

Lewis, S., \& Lingard, B. (2015). The multiple effects of international large-scale assessment on education policy and research. Discourse: Studies in the Cultural Politics of Education, 36(5), 621-637. https://doi.org/10.1080/01596306.2015.1039765

Lodge, J. M., \& Bonsanquet, A. (2014). Evaluating quality learning in higher education: Re-examining the evidence. Quality in Higher Education, 20(1), 3-23. https://doi.org/10.1080/13538322.2013.849787

Macdonald, K. (2014). The meaning and purposes of transnational accountability. Australian Journal of Public Administration, 73(4), 426-436. https://doi.org/10.1111/1467-8500.12107

Marshall, S. J. (2018). Shaping the university of the future. Singapore: Springer. https://doi.org/10.1007/978-981-10-7620-6

Mense, E. G., Lemoine, P. A., Garretson, C. J., \& Richardson, M. D. (2018). The development of global higher education in a world of transformation. Journal of Education and Development, 2(3), 47. https://doi.org/10.20849/jed.v2i3.529

Moodie, G. (2016). Universities, disruptive technologies, and continuity in higher education: The impact of information revolutions. New York, NY: Springer. https://doi.org/10.1057/978-1-137-54943-3

Moore, C., \& Greenland, S. (2017). Insights for future assessment policy: Open access online higher education. Journal of Open, Flexible, and Distance Learning, 21(1), 52-62.

Pucciarelli, F., \& Kaplan, A. (2016). Competition and strategy in higher education: Managing complexity and uncertainty. Business Horizons, 59(3), 311-320. https://doi.org/10.1016/j.bushor.2016.01.003

Sabio, R. A., \& Junio-Sabio, C. (2014). Concerns for quality assurance and excellence in higher education. International Journal of Information Technology and Business Management, 23(1).

Srivastava, M., \& Suman, S. (2018). Disruption in open and distance learning: Survival quest of open universities in the digital age. Indian Journal of Open Learning, 27(1), 3-18.

Tam, M. (2014). Outcomes-based approach to quality assessment and curriculum improvement in higher education. Quality Assurance in Education, 22(2), 158-168. https://doi.org/10.1108/QAE-09-2011-0059

Tang, H. H. H. (2018). Academic profession, entrepreneurial universities and scholarship of application. Journal of Comparative \& International Higher Education, 10(Winter), 3-5. https://doi.org/10.32674/jcihe.v10iWinter.683

Thambusamy, R. X., Singh, P., \& Ramly, M. A. (2019). The inconvenient truth about digital transformation in higher education. In Y. Inoue-Smith (Ed.), Faculty roles and changing expectations in the new age (pp. 232-247). Hershey, PA: IGI Global. https://doi.org/10.4018/978-1-5225-7438-5.ch014

Tierney, W. G., \& Almeida, D. J. (2017). Academic responsibility: Toward a cultural politics of integrity. Discourse: Studies in the Cultural Politics of Education, 38(1), 97-108. https://doi.org/10.1080/01596306.2015.1104855 
West, D., \& Thompson, S. (2015). Mobile knowledge: Driving a paradigm shift. Journal of Applied Research in Higher Education, 7(1), 43-54. https://doi.org/10.1108/JARHE-02-2014-0021

Wihlborg, M., \& Robson, S. (2018). Internationalisation of higher education: Drivers, rationales, priorities, values and impacts. European Journal of Higher Education, 8(1), 8-18. https://doi.org/10.1080/21568235.2017.1376696

\section{Copyrights}

Copyright for this article is retained by the author(s), with first publication rights granted to the journal.

This is an open-access article distributed under the terms and conditions of the Creative Commons Attribution license (http://creativecommons.org/licenses/by/4.0/). 